\title{
The Italian Way: Urban Planning Heritage in Albania
}

Giuseppe Resta, Politecnico di Bari

\begin{abstract}
The paper is focused on ageism in urban planning, taking the Italian WWII planning heritage in Albania as a case study. It expounds three main issues: acknowledgment of modern heritage, dissemination of autocratic identity, and historical planning apparatus. The text investigates autocratic plans as purest fulfilment of Euclidean space, before relentless urban transformations affect cities.
\end{abstract}

Keywords - Albania, autocratic space, cultural identity, Italian square, town Planning heritage.

\section{The ItALiAn WaY}

\section{A. Acknowledgment of Modern Heritage}

Albania is going through a rapid growth stage in the core of the Balkan Peninsula, the sole dynamic geopolitical context in the “old” Europe. Slavoj Žižek, the Slovenian Marxist philosopher, claims that the Balkans is unconscious of Europe. He treats the entire region as a subject with a failing oedipal structure, which Žižek attributes to the absence of a Cartesian tradition and proper symbolic authority [1]. Since we live in an age of no interruptions, lacking intervals, the most powerful means of communication of architecture is not so much the building itself (fleeting experience) as its media reflection [2]. Indeed, it is possible to experience urban space through an electronic interface, even before one's physical experience: perception is flattened on a surface that creates a short-circuit that gathers a certain amount of information controlled by a subjective source (point of view). On the contrary, recent buildings manage to be media-friendly and photogenic, captivating at first, sight at a distance.

Albania's anxiety to renovate the image of the new democracy, after it has endured two consecutive dictatorships lasting almost the entire XX century, gave way to a heavy "upgrade" attitude towards the urban tissue. In Tiranë, for example, a series of towers popped-out in the even skyline of the city, starchitects delivered landmarks as modernization tool. And jumbo screens, random patterns, and glass facades formed the new architectural order.

Tiranë has once been an "old Roman centre, Ottoman outpost, Italian Novecento archetype, Fascist utopian dream, an example of Stalinist brutalism, and finally, a model of contemporary (non) architecture run amok." This is the blunt description by Arlinda Dudaj, Helidon Gjergji, and Vladimir Myrtezai-Grosha, directors of the recent Tirana Open. This position on contemporary urbanism reveals the dissatisfaction of intellectuals. Furthermore, there are plenty of bad examples, all around Europe, of senseless destruction of wartime heritage.

The form's consumption, dominating contemporary aesthetics, is produced by swift alternation of visual codes and ideological structures. The paradox is that ours is the period in which architectural form can be recovered most rapidly, to be preserved beyond visual obsolescence, with philological ease.

Modernist urban space is a period costume, perceived as obsolete while the lifespan of buildings is drastically reduced.

Fascism created "Cartesian spaces" moulded by four main design tools: pure volumes, colours and materials, rhythms, and scales. In few years, a huge shift happened. In 1990s, architecture entered into the new field of non-Euclidean geometry: "Perhaps one day this century will be known as Deleuzian", predicted Foucault in 1970 addressing Deleuze's discourse, and referring to spatiality he suggested that "the circle must be abandoned as a faulty principle of return; we must abandon our tendency to organise everything into a sphere. All things return into straight and narrow, by way of a straight and labyrinthine line. Thus, fibrils and bifurcations (Leiris' marvellous series would be well suited to a Deleuzian analysis)" would better represent the forthcoming spatial layout [3]. While Foucault challenged traditional forms such as circles and spheres, Deleuzian spatiality dominates today's architecture. It evolves from three main paradigms: fold as bending of surfaces, parametricism as formal creation, and biomorphism as imitation of biologic growth. Their common ground is the software as the sole instrument controlling the complex design process [4].

Wartime spaces, like the ones from fascism, are meant to be archaeology. They address aesthetic codes that will not return. Being deprived of political implications, they should be studied and properly preserved as powerful utterance of propaganda and positivism.

\section{B. Dissemination of Autocratic Identity}

Italy considered Albania as an extension of its own territory rather than a colony, in the ruinous dream of a new Roman Empire. A major architectural issue is the way western modernism, passing through a rigid dictatorship and all the propaganda implications, plunged into an Ottoman built environment.

It is both a theoretical and concrete issue: How do we define the features that constitute the body of Western European architectural identity? Which is the image planned on the table, with a defined degree of flexibility, delivering the values of the regime? How does it adapt to the "conquered" milieus?

The "Italian way" had to be a point of balance between modernism and Mediterranean culture, namely the prototype of a new classical-oriented civilization. Therein the role of propaganda periodicals is critical, some of them were dedicated to each controlled country, responsible for publishing schemes and models for designers. Established in December 1940, the publishing body DISTAPTUR conducted political, social, 


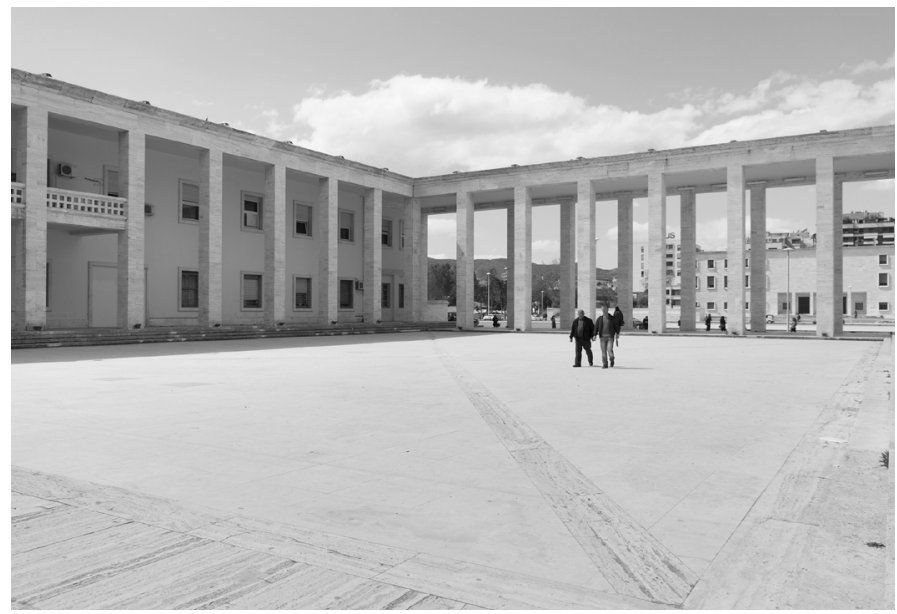

Fig. 1. Square of the Gioventù del Littorio Albanese building in Tiranë [19].

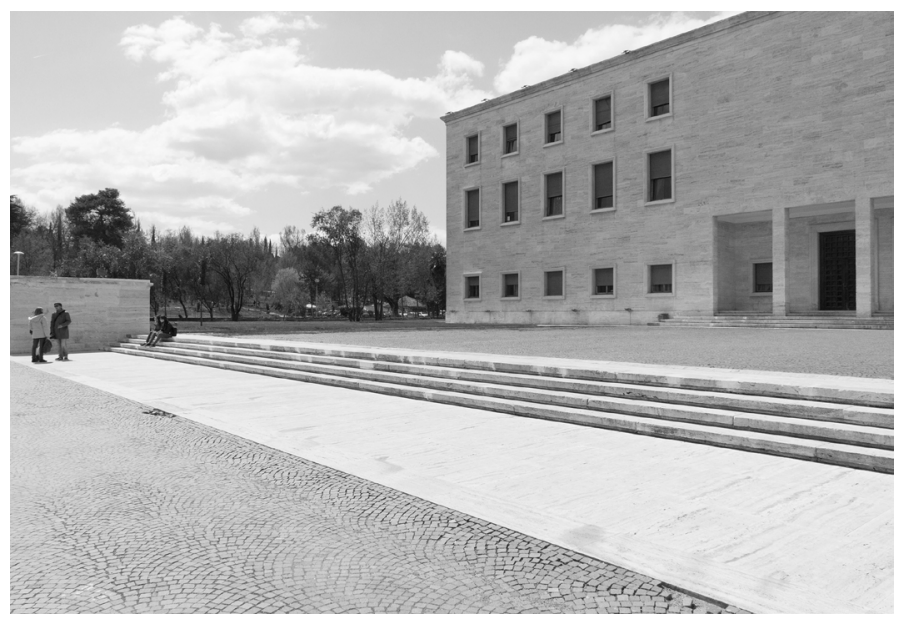

Fig. 2. Opera del Dopolavoro Albanese building in Tiranë [19].

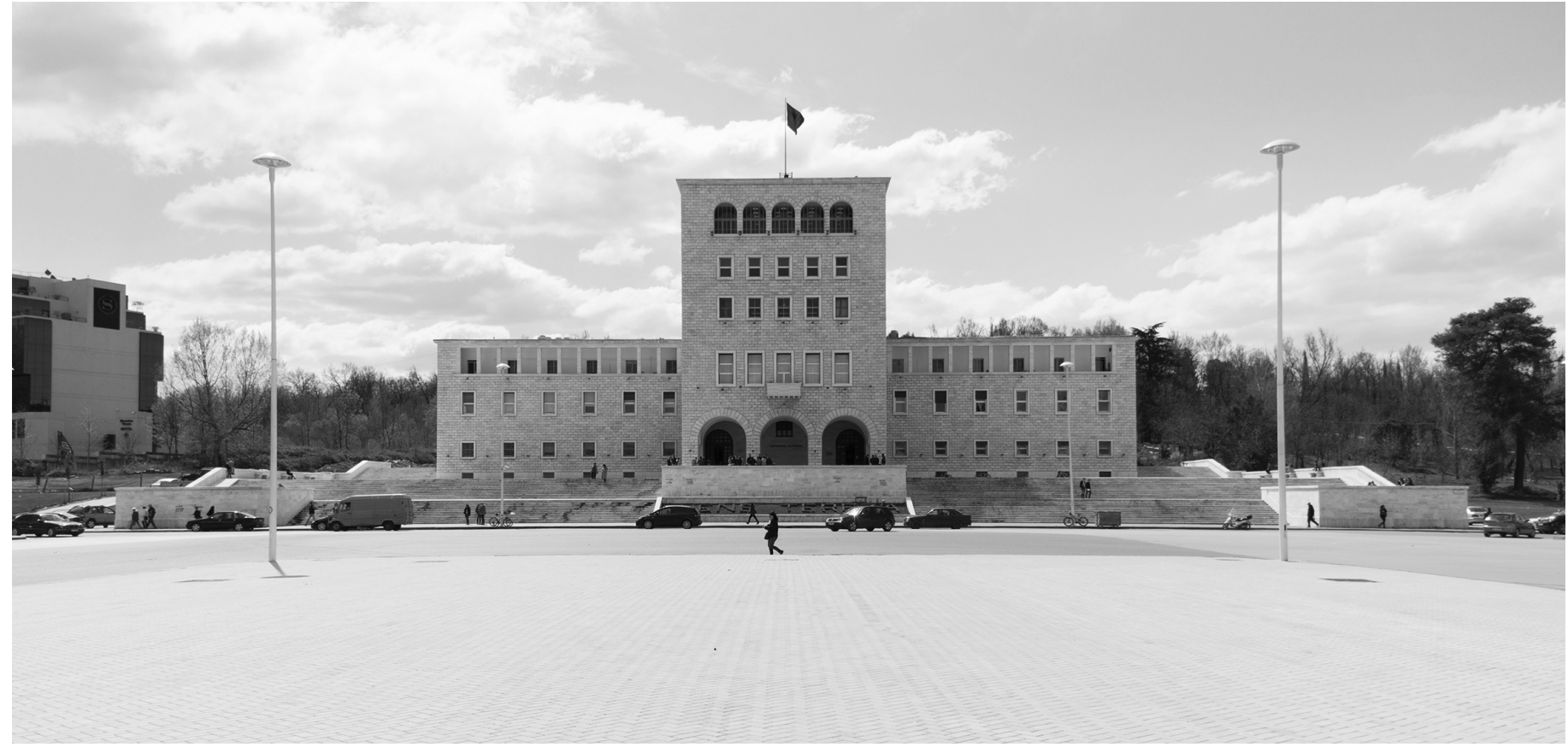

Fig. 3. Piazza del Littorio in Tiranë [19].

economic, and touristic propaganda. Bilingual editions were aimed at connecting the two shores of the Adriatic Sea.

Between 1940 and 1943, the publishing body produced several books, Drini (monthly bulletin of Albanian tourism), and roughly 400 postcards of landscapes or traditional costumes. Additional Italian publications were Tomori ("Fascist daily of Albania"), Tomori $i$ vogël (weekly supplement of the former), Fashizëm, and Albania-Shqipni printed in Rome. In the first issue of AlbaniaShqipni, Galeazzo Ciano (the minister of foreign affairs) writes that the periodical has to "carry out smart and constant work towards an increasingly greater mutual understanding of the two populations joined in the imperial community of Rome". While the regime treated other Italian possessions as places to be civilized [5], the Albanian propaganda unearthed common roots back to the Roman Empire. It is not surprising that a picture of the "head of Augustus found in Butrint", during the Italian archaeological excavations in the South, faces the words by Galeazzo Ciano.

The debate over colonial architecture was very vivid in Rome: it implied a precise description of the regime's theoretical pillars to which designers would eventually refer. Carlo Enrico Rava participated from the pages of Domus. He blamed the pursuit of the picturesque by architects designing for Italian possessions [6]. The composition, instead, should have consisted of rational plans, plain volumes, and hues of Mediterranean tradition as "durable proof of our actual greatness" [7]. Rava rejected the label of "German-like architecture": the classical substratum guarantees profound independence and originality. Nor it can be labelled as "style", he says, since rational architecture "overcomes the people who produced it" embodying a new "Hellenic spirit" [8]. 
TABLE I

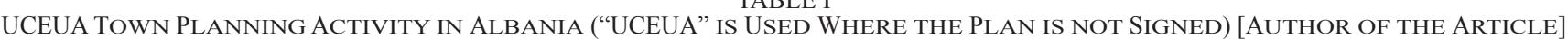

\begin{tabular}{|l|l|l|}
\hline City & Year & Authors \\
\hline Berat & $1939-1942$ & Bosio, Moz \\
\hline Burrel & $1938-1942$ & Bertè, UCEUA \\
\hline Durrës & 1942 & Carmignani, Poggi \\
\hline Elbasan & $1939-1942$ & Bosio, Lambertini, Poggi \\
\hline Korça & $1939-1940$ & Bosio, Orzali, Poggi \\
\hline Milot & 1941 & UCEUA \\
\hline Petrelë & 1940 & UCEUA \\
\hline Sarandë & $1940-1942$ & Bosio, Carmignani, Paladini, Poggi \\
\hline Shkodër & $1939-1941$ & Bosio, Poggi \\
\hline Tiranë & $1939-1943$ & Bosio, Lambertini, Poggi \\
\hline Vlorë & $1939-1942$ & Bosio, Paladini, Poggi \\
\hline
\end{tabular}

Rava, with other architects like Frette, Larco, Figini, Pollini, and Libera, established the Gruppo 7, which endorsed the publicity of rationalism. The Lombard architecture was particularly interested in the debate on national identity and its relationship with "exotic" cultures acquired abroad. The roman exhibitions of MIAR between 1928 and 1931; Bardi and Bontempelli's Quadrante periodical; Persico and Pagano on the pages of Casa Bella were the key moments of the inception of Italian modernism, which looked at Gropius, Le Corbusier, and Mies van der Rohe as guides.

If one has to pick the projects that served as built milestones for the following Italian modernism, it would probably be the university campus of Rome (1932-1935), Florence Santa Maria Novella train station (1933-1935) and Sabaudia urban plan (1934) [9]. The chief architect of the Roman campus is Marcello Piacentini who designated a group of young designers (e.g., Ponti, Pagano, and Michelucci) to design the faculty buildings. It sounded like an investiture as champions of the architectural debate over national modernism and actually they seemed to avoid personal styles towards a simple composition of volumes. In Florence, the team led by Giovanni Michelucci designed the first convincing modern building facing a strong historical context and functional needs. Finally, Sabaudia was the essence of the fascist town based on the Cardo and Decumano and a new territorial planning strategy for land improvement.

The debate over architectural identity showed contradictions between the style for a modern State and the image of a spiritual regime. Architecture, seen as a moral agency gathering social tasks, faced the commitment to represent an autocratic ideology pretending to be rational. Yet Mustafa Merlika Kruja, the later prime minister of Albania during Italian occupation, revealed the same discrepancy in his speech, on 12 April 1939, for the National Constituent Assembly that offered the crown of Albania to the King of Italy. Speaking on behalf of Albanian people, Kruja swore allegiance to Rome as bearer of a new civilization that is "tradition and revolution at the same time" [10]. "Europe needs a New Order" since fascist revolution "is not meant to be enclosed inside national boundaries", he claimed. "The Duce acquires, to us Albanians, more sacred qualities" towards a "Fascist social religion" to accomplish the "historical mission assigned to Skanderbeg". While politicians fabricated historical connection proving them as heirs of Roman Empire, the need for religion was channelled to the figure of the Duce. His speech that day mentioned the word "faith" 15 times [10]. The agreement signed in Tiranë, eight days later, let Italians participate in Albanian public affairs and institutions [11]. Let us consider that faking historical connections with magnificent empires is quite common among dictators to prove a sort of fatalism: Saddam Hussein, addressing Ur and its 5000-year-old monumental tradition, is only a recent example $[12,8]$.

\section{Historical Planning Apparatus}

The early 40s is probably the last period in Europe mn during which architects experimented on all scales of the design at the same time, "from the spoon to the city" to use the words by Ernesto Nathan Rogers. The last totalizing ambition for design before the thriving of specialist fields in urban and architectural design. In Italy, the restoration of the position of the architect, into the process of social development, was a major issue. Gustavo Giovannoni, who was instrumental in the establishment of the Scuola Superiore di Architettura in Rome, proposed the "architetto integrale" (complete architect) for the purpose: a "true architect, that is an artist, technician and cultured person at the same time" [13].

In 1939, Italy established the central town-planning office in the capital, the Ufficio Centrale per l'Edilizia e l'Urbanistica dell'Albania (UCEUA), and spent five years to produce 11 urban plans all around the country (with different degree of detailing), civil infrastructures, and amenities. Gherardo Bosio, the Florentine architect who spearheaded most of the Office's activities, acted as architetto integrale in Albania. He ranged from territorial planning process to technical details of smallsize buildings [14]. When Bosio died in 1941, Giuseppe Paladini, Leone Carmignani and Ferdinando Poggi took his place until the German Occupation in 1943. See Table I presenting the town planning activity. 


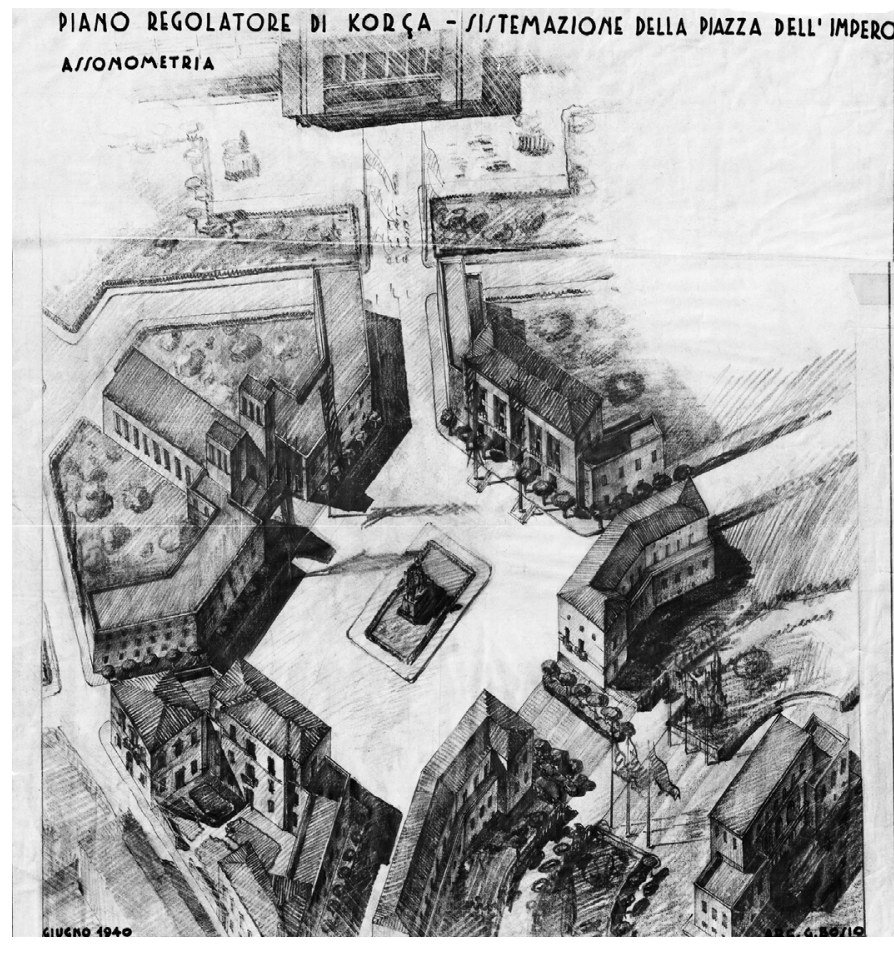

Fig. 4. Axonometric view of the square, Master Plan of Korça (1940) [20].

The core of autocratic town planning was the public space, to which individual buildings had to adapt. Designers "established sites for adunate, the mass rallies at which the fascist citizenry collectively and ritually celebrated the state's secular mythology. These spaces helped create and reinforce the mass identity mandated by the regime, and they existed alongside (or overlapped) the spaces devoted to everyday commerce, recreation, and education" [15].

Since Tiranë was cluttered with drab houses, the new capital needed a modern district built from scratch in the south side. Skanderbeg square connected the old town with the "New Tiranë", concentric ring roads tied the neighbourhoods, and the monumental boulevard served as a new spine for the centre [14].

Its commercial counterpart, facing the sea, was Durrës. There the regime planned to construct one of the most important ports of the Adriatic Sea. Urban expansion was bound to massive land remediation and the use of the coast for touristic purposes and leisure activities.

Vlorë and Sarandë ought to be the second and the third ports of Albania, respectively. While the plan for Vlorë followed the same principles of the cities described above (and a strict zoning law), Sarandë included a new extensive residential area for 10000 inhabitants with gardens and new public spaces, overlooking the bay.

Berat and Shkodër, which rely on high landscape value, are treated differently. The plans, designed up to the regional scale, maintained "picturesque style", avoided uniform urbanization, adapted to the terrain conquering new spots. This highlights that "the economic role of Albania, in the new imperial framework, would be of agricultural, pastoral, and forestry nature" [16, 246].

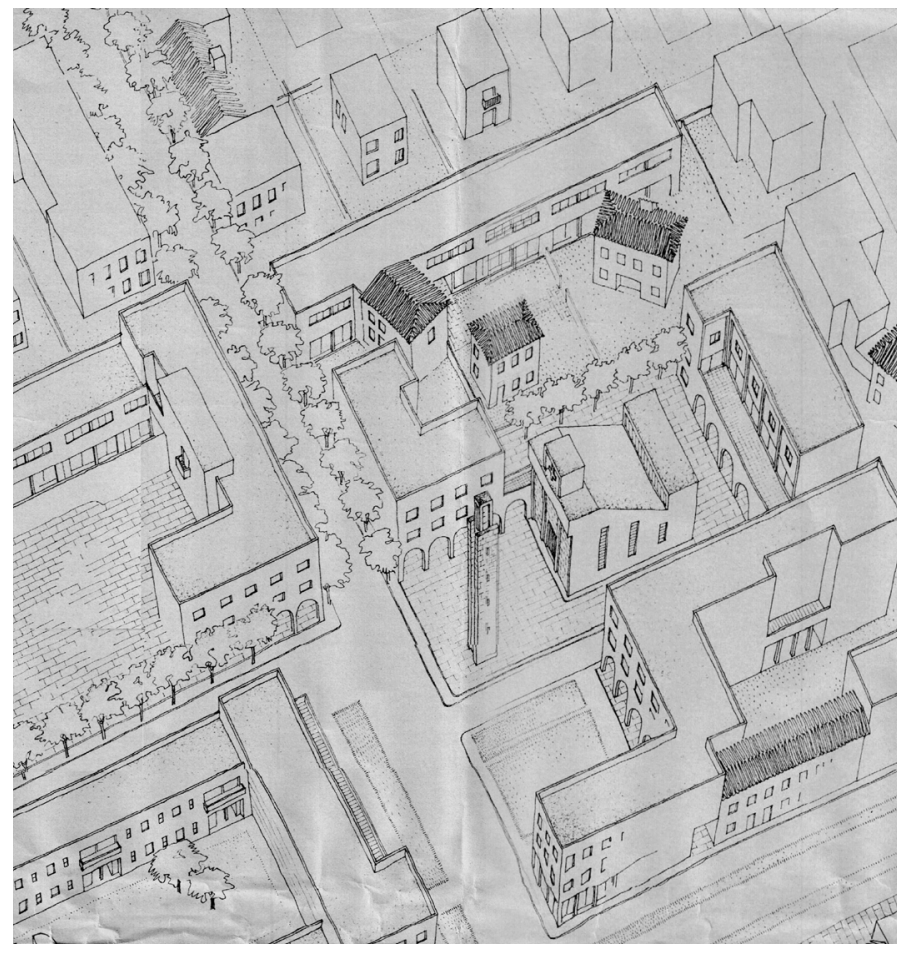

Fig. 5. Axonometric view of the square, Master Plan of Milot (1941) [20].

Water management and infrastructures were the main problems to deal with.

Elbasan and Milot, as well as Tiranë, had to face floods and lack of embankments. The river became an urban structure to let people use the bank as a linear park. Those inland cities, along with Burrel, have a clear scheme: a representative road through high-density blocks, the extensive rural housing around, and a small productive district, planned in the first instance, as they were economy driving.

Small settlements, like Korça and Petrelë, were arranged around the town square with isolated buildings and the mosque. Architecture was inclined to some local features and materials while Italian garden design integrated into the wild land.

Albanian urban fabrics changed their dimension due to introduction of new typologies of buildings (villa, palace, hospital, school, ministry building, bank, railway station, hotel and post office) as well as new urban spaces: the monumental boulevard, waterfront walkway and, above all, the Italian piazza. Existing mosques, formerly built to be condenser of people's activities, were freed from dense residential neighbourhood and isolated as monument of the past. They served as an ending scene of large streets, cutting the core of the city, abreast of new sensibility for speed and movement introduced by car as mass means of transportation.

Though all the plans vary in scale, program and status of implementation, the main target would be the recognition of their common theoretical structure, physically conveyed by autocratic spaces. Town-planning was a large scale architectural project of a metaphysical nature, shaping a scene that was classical and abstract at the same time. The minimum fascist 
configuration was the cardo-decumano scheme, crisscrossed in the rectangular square (Forum) where the space is enclosed with porticos and the entrances through the street are not aligned.

Now, after 72 years that the regime left Albania, ageism towards autocratic spaces leads to the topic of renovation of the city [17]. It is a dialogue between current corporation-driven development and centralized national planning, both addressing the stereotypes shown in the table.

The frame of the debate about the twentieth century heritage in Albania should include urban spatial structures and public spaces rather than building itself.

While fascist buildings hardly compete with fifty-meter towers, occurring as outdated monumentality, they could rely on timeless spaces, squares, and courtyards made of archetypical elements. They convey a "built metaphysics" [17], as if history were freed from material implications. In other words, construction that had been liberated from time.

The alienation arousing in those places is quite uncommon: space represents itself as patterns of ordering. To use Foucault's words about the structure of scientific thinking that is spreading to other sciences, the city is "a tabula, that enables thought to operate upon the entities of our world, to put them in order, to divide them into classes, to group them according to names that designate their similarities and their differences - the table upon which, since the beginning of time the language has intersected space" [18].

Some regional and urban plans achieved a good value in line with the latest international trends conveying, in some cases, advanced experimentation. It would be worthwhile if autocratic spaces could be officially surveyed, to be included as "historical island" into the next stage of town planning.

\section{REFERENCES}

1. Bjelić, D. I. Is the Balkans the Unconscious of Europe? Psychoanalysis, Culture \& Society, Vol. 16, Issue 3, 2011, p. 315-323. Available also at: http://dx.doi.org/10.1057/pcs.2011.11

2. Virilio, P. L'espace critique : essai sur l'urbanisme et les nouvelles technologies. Paris: Christian Bourgois, 1984. 195 p.

3. Bouchard, D. F. Intellectuals and Power. Language, Counter-Memory, Practice: Selected Essays and Interviews [M. Foucault, ed.]. Ithaca: Cornell University Press, $240 \mathrm{p}$.

4. Fontana-Giusti, G. Foucault for Architects. New York: Routledge, 2013. $200 \mathrm{p}$.

5. Metafisica costruita [R. Besana, C. F. Carli, L. Devoti, L. Prisco, ed.] Milan: Touring Club Editore, 2002. 255 p.

6. Rava, C. E. Per la casa e la vita in colonia. Domus, Vol. 158, 1941, p. $61-63$.

7. Rava, C. E. Di una architettura coloniale moderna. Domus, Vol. 42, 1931, p. 32-36.

8. Rava, C. E. Dell'europeismo in architettura. Rassegna Italiana, Vol. 21, Issue 2, 1928, p. 133-140.

9. Ciucci, G. Gli architetti e il fascismo. Turin: Giulio Einaudi Editore, 2002 $246 \mathrm{p}$.

10. Kruja, M. M. L'Albania nell'Ordine Nuovo. Albania-Shqipni, Vol. 3, Issue 2, 1942, p. 286-299.

11. Pierantoni, A. I rapporti italo-albanesi. Albania-Shqipni, Vol. 1, Issue 6, 1940, p. 231-239.

12. Sudjic, D. The Edifice Complex : The Architecture of Power. London: Penguin Press, 2005. 464 p.

13. Giovannoni, G. Gli architetti e gli studi di Architettura in Italia. Rome: Unione Editrice, 1916. 153 p.

14. Menghini, A. B. Architettura moderna italiana per la città di Tirana
Architettura moderna italiana per le città d'Albania [A. B. Menghini, F. Pashako, M. Stigliano, ed.]. Tiranë: Botimet Dudaj, 2012.

15. Rifkind, D. Gondar : Architecture and Urbanism for Italy's Fascist Empire. Journal of the Society of Architectural Historians, Vol. 70, Issue 4, 2011, p. 492-511. Available also at: http://dx.doi.org/10.1525/ jsah.2011.70.4.492

16. Posca, L. Architetti italiani in Albania : 1914-1943. Rome: Clear, 2013. 298 p.

17. Belli, P. R., Menghini, A. B., Pagliarulo, R. Knowledge and enhancement of architectural and archaeological heritage : the Palace of GLA in Tirana. Proceedings of the 2nd ICAUD International Conference in Architecture and Urban Design. Epoka University, Tirana, Albania, 08-10 May, 2014 [cited 11.09.2015]. http://dspace.epoka.edu.al/bitstream/handle/1/948/135 pdf? sequence $=1$

18. Foucault, M. The Order of Things : An Archaeology of the Human Sciences. (Translated by A. M. Sheridan Smith). London, New York: Routledge, 1991. 449 p.

19. Photo by Benedetto Suriano, Tiranë, 2015.

20. Arkivi Qëndror Teknik i Ndërtimit (AQTN) [cited 05.09.2015]. http://www. aqtn.gov.al/

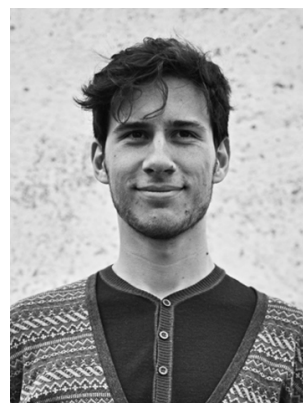

Giuseppe Resta received the degree of M. arch from Politecnico di Bari. He is a PhD. student in "Architecture: innovation and heritage" program with Università degli studi RomaTRE (Rome, Italy). He is an Assistant with the Department of Architecture and Civil Engineering, atelier of Architecture III, Politecnico di Bari, (Bari, Italy). $\mathrm{He}$ regularly participates at international conferences and is an editor at the Artwort Magazine. His published work has appeared in several architectural magazines (e.g., STUDIO magazine, Lunch journal, T3xture). He has been one of the curators of the exhibition "Evoked. Architectural diptychs" (Tirana, February to March 2016) dealing with informal development on Albanian coast. His main research interests are The Balkans, space and power relationship, visual culture of mixed-use buildings.

$\mathrm{He}$ is a licensed Architect (Bari, Italy) and participates at architectural competitions. He won the third prize in the International Concept and Design Competition in Architecture "Start Metronapoli" for the Montesanto metro station (2012, Napoli). He participated in exhibitions "Last but not least" (2012, Gioia del Colle); "Forme alla deriva" at MICROBA art gallery (2014, Bari).

\section{CONTACT DATA}

\section{Giuseppe Resta}

Politecnico di Bari, Department of Architecture and Civil Engineering

Address: 4 Via Orabona, Bari, 70125, Italy

Phone: +393498972110

E-mail: giuseppe.resta@uniroma3.it giusepperesta.arch@gmail.com 